\title{
Two New Lactones and One New Aryl-8-oxa-bicyclo[3,2,1]oct-3-en-2-one from Descurainia sophia
}

\author{
Kai Sun, ${ }^{a}$ Xian LI, ${ }^{* a}$ Wen Li, ${ }^{b}$ Jinhui W ${ }_{\text {ANG }},{ }^{a}$ Jianming LiU, ${ }^{c}$ and Yi SHA ${ }^{b}$ \\ ${ }^{a}$ Research Department of Natural Medicine, Shenyang Pharmaceutical University; ${ }^{b}$ The Center of Instrumental Analysis, \\ Shenyang Pharmaceutical University; Shenyang 110016, P. R. China: and ${ }^{c}$ Research Department, Yisheng \\ Pharmaceutical Co. Ltd.; Ji'an 134200, P. R. China. Received July 4, 2004; accepted September 21, 2004
}

Two new lactones $(1,2)$, descurainolide $A$ and $B$, and one new aryl-8-oxa-bicyclo[3,2,1]-oct-3-en-2-one (3), descurainin, together with five known compounds $(4-8)$, were isolated from the seeds of Descurainia sophia (L.) Webb ex Prantl. The structures of the new compounds were elucidated by extensive studies of their 1D, 2D NMR and HR-MS. Compounds 4 and 5 showed cytotoxicity.

Key words Descurainia sophia; lactone; aryl-8-oxa-bicyclo[3,2,1]-oct-3-en-2-one; nor-lignan; cytotoxicity

Descurainia sophia (L.) WeBB ex PRANTL is widely distributed in the northeast of China, and its seeds are used in China as a Chinese traditional medicine to relieve a cough, prevent asthma, reduce edema, promote urination and have a cardiotonic effect. In some cases the seeds can also be used in the treatment of some cancers. ${ }^{1)}$ In the previous chemical studies, it was reported the isolation of some cardiac glycosides, ${ }^{2)}$ flavonoids and phenols ${ }^{3)}$ from the seeds. As our current interest in the medicinal uses of the seeds of $D$. sophia, we also carried out a phytochemical investigation on the seeds of $D$. sophia, which resulted in two new lactones, descurainolide $\mathrm{A}$ and $\mathrm{B}(\mathbf{1}, \mathbf{2})$, and a new aryl-8-oxa-bicyclo[3,2,1]-oct-3-en-2-one, descurainin (3), together with five known compounds. All the three new compounds we got possess the same 4-hydroxy-3,5-dimethoxy-phenyl moiety, and sinapic acid moieties or sinapic acid derivate moieties can be found in their structures. Therefore it seems that the three new compounds are related to sinapic acid or sinapic acid derivates in biosynthesis. As a part of my research, that will be carried out in the future. This paper deals with the isolation and structural elucidation of the new constituents on the base of extensive studies of their 1D and 2D NMR and HR-MS, and cytotoxicity of the isolated compounds towards 6 human cancer cell lines.

The ethanolic extract of the seeds of $D$. sophia was subjected to column chromatography on macroporous resin D101. Separation of the $40 \%$ ethanol eluate on a silica open column yielded eight compounds. The known compounds 4 -8 were determined to be strophanthidin (4), ${ }^{4)}$ isorhamnetin-3- $O-\beta$-D-glucopyranoside $(5),{ }^{5)}$ sinapic acid ethyl ester $(6),{ }^{3)}$ isorhamnetin $(7)^{5)}$ and quercetin-3- $O-\beta$-D-glucopyranoside $(\mathbf{8})^{6}$ by analysis of the physical and spectroscopic evidence, and confirmed by comparing with the literature data.

Compound 1 was obtained as colorless needles. It responded positively to the $\mathrm{FeCl}_{3}$ reagent. The molecular formula of $\mathrm{C}_{13} \mathrm{H}_{16} \mathrm{O}_{5}$ was deduced from HR-ESI-MS spectrum. ${ }^{1} \mathrm{H}-,{ }^{13} \mathrm{C}-\mathrm{NMR}$ spectra (Tables 1,2 ) and HMQC of $\mathbf{1}$ indicated a 4-hydroxy-3,5-dimethoxy-phenyl moiety at $\delta_{\mathrm{H}} 3.75$ $(6 \mathrm{H}, \mathrm{s}), 6.66(2 \mathrm{H}, \mathrm{s})$ and $8.26(1 \mathrm{H}, \mathrm{s}), \delta_{\mathrm{C}} 56.1(2 \mathrm{C}), 105.3$ $(2 \mathrm{C}), 128.6,134.8$ and $148.1(2 \mathrm{C})^{3)}$; one methyl group at $\delta_{\mathrm{H}}$ $1.27(3 \mathrm{H}, \mathrm{d}, 6.0 \mathrm{~Hz})$ which suggested a connection with one methine group, $\delta_{\mathrm{C}} 18.6$; a methylene group at $\delta_{\mathrm{H}} 2.92(1 \mathrm{H}$, $\mathrm{dd}, 17.1,11.4 \mathrm{~Hz})$ and $2.76(1 \mathrm{H}, \mathrm{dd}, 17.1,8.4 \mathrm{~Hz}), \delta_{\mathrm{C}} 37.1$; a methine group at $\delta_{\mathrm{H}} 3.17(1 \mathrm{H}, \mathrm{m}), \delta_{\mathrm{C}} 49.0$; another methine group attached to an oxygen atom at $\delta_{\mathrm{H}} 4.51(1 \mathrm{H}, \mathrm{m}), \delta_{\mathrm{C}}$ 82.4; and a lactone carbonyl group at $\delta_{\mathrm{C}} 175.6$. In addition, six degrees of unsaturation, among which four were attributed to the phenyl moiety and one was caused by the carbonyl group, confirmed the presence of a lactone ring. The deduction of C-5 connecting with the oxygen atom on the lactone ring was supported by the chemical shifts of $\mathrm{H}-5$ and C-5. The connecting order of C-2, C-3, C-4 and C-5, and the substitutions of $\mathrm{C}-4$ by the phenyl group and $\mathrm{C}-5$ by the methyl group were determined, respectively, via HMBC (Fig. 1) which exhibited the cross peaks: $\mathrm{C}-1^{\prime}$ with $\mathrm{H}-3 \alpha$ and $\mathrm{H}-5$; C-2 with H-5; C-4 with H-2', 6' and 5-Me. In the NOESY spectrum, the cross peaks: $\mathrm{H}-4$ with $5-\mathrm{Me}$; H-2' $6^{\prime}$ with $\mathrm{H}-5$, revealed the relative configuration of $\mathbf{1}$ : the trans-orientation of the phenyl moiety and 5-Me. Thus, the structure of descurainolide A (1) was elucidated as 4-(4-hydroxy-3,5dimethoxy-phenyl)-5-methyl-dihydro-furan-2-one.

Compound 2 was obtained as colorless needles and responded positively to the $\mathrm{FeCl}_{3}$ reagent. The HR-ESI-MS of 2 suggested the molecular formula of $\mathrm{C}_{21} \mathrm{H}_{22} \mathrm{O}_{8}$. The NMR spectra (Tables 1, 2) and the HMQC spectrum of $\mathbf{2}$ revealed two 4-hydroxy-3,5-dimethoxy-phenyl moieties ${ }^{3)}$; a double bond group $(-\mathrm{CH}=\mathrm{C}-)$ at $\delta_{\mathrm{H}} 7.42(1 \mathrm{H}, \mathrm{brs}), \delta_{\mathrm{C}} 135.9$ and 130.2; a methylene group at $\delta_{\mathrm{H}} 3.69(1 \mathrm{H}$, br dd, $17.7,7.2 \mathrm{~Hz})$ and $3.22(1 \mathrm{H}, \mathrm{dd}, 17.7,7.2 \mathrm{~Hz}), \delta_{\mathrm{C}} 35.4$; a methine group substituted by an oxygen atom at $\delta_{\mathrm{H}} 5.52(1 \mathrm{H}, \mathrm{t}, 7.2 \mathrm{~Hz}), \delta_{\mathrm{C}}$ 78.6; and a lactone carbonyl group at $\delta_{\mathrm{C}}$ 171.7. Compared with 2-(4-hydroxy-3,5-dimethoxy-phenyl)-4-(4-hydroxy-3,5dimethoxy-benzylidene)-5-oxo-tetrahydro-furan-3-carboxylic acid (9), ${ }^{7}$ it was inferred that 2 possessed the similar structure to 9 and 3-carboxylic acid on the lactone ring of 9 was substituted by a hydrogen atom. The chemical shifts of H-5 and C-5 indicated the carbon to C-5 linked with the oxygen atom belonging to the lactone ring of 2 . In the HMBC spectrum (Fig. 2), the connection of $\mathrm{C}-7^{\prime}$ to $\mathrm{C}-1^{\prime}$, the position of the double bond $3\left(7^{\prime}\right)$, the substitution of $\mathrm{C}-5$ by $\mathrm{C}-1^{\prime \prime}$, and the connecting order of the lactone ring were confirmed respectively by the cross peaks: C-7' with $\mathrm{H}-2^{\prime}, 6^{\prime}$; and $\mathrm{C}-2^{\prime}$, $6^{\prime}$ with $\mathrm{H}-7^{\prime}$; C-2 and C-4 with $\mathrm{H}-7^{\prime}$; C-2", 6" with $\mathrm{H}-5$; and C-5 with H-2", 6"; C-2 with $\mathrm{H}-5$; and C-1" with $\mathrm{H}-4 \alpha, 4 \beta$. The orientation of the double bond $3\left(7^{\prime}\right)$ was supported by comparison with the known compound and the NOESY experiment. The chemical shift of $\mathrm{H}^{-7^{\prime 8)}}$ and the cross peak of $\mathrm{H}-2^{\prime}, 6^{\prime}$ with $\mathrm{H}-4 \alpha$ intimated the trans-orientation of the 
Table 1. ${ }^{1} \mathrm{H}-\mathrm{NMR}$ Spectral Data for Compounds $\mathbf{1}, \mathbf{2}$ and $\mathbf{3}$ (in DMSO- $\left.d_{6}, 300 \mathrm{MHz}\right)^{a}$

\begin{tabular}{|c|c|c|c|}
\hline $\mathrm{H}$ & 1 & 2 & 3 \\
\hline 1 & & & 4.51 br d $(8.1)$ \\
\hline \multicolumn{4}{|r|}{ (1) } \\
\hline $3 \alpha$ & $2.92 \mathrm{dd}(17.1,11.4)$ & & $6.19 \mathrm{~d}(9.9)$ \\
\hline $3 \beta$ & $2.76 \mathrm{dd}(17.1,8.4)$ & & \\
\hline $4 \alpha$ & & 3.69 br dd $(17.7,7.2)$ & $6.82 \mathrm{~d}(9.9)$ \\
\hline $4 \beta$ & $3.17 \mathrm{~m}$ & $3.22 \mathrm{dd}(17.7,7.2)$ & \\
\hline 5 & $4.51 \mathrm{~m}$ & $5.52+(7.2)$ & \\
\hline 6 & & & $3.45 \mathrm{dd}(10.2,7.2)$ \\
\hline $7 \alpha$ & & & $2.83 \mathrm{~m}$ \\
\hline $7 \beta$ & & & $1.92 \mathrm{dd}(13.5,7.2)$ \\
\hline $2^{\prime}, 6^{\prime}$ & $6.66 \mathrm{~s}$ & $6.93 \mathrm{~s}$ & $6.41 \mathrm{~s}$ \\
\hline $7^{\prime}$ & & $7.42 \mathrm{brs}$ & \\
\hline $2^{\prime \prime}, 6^{\prime \prime}$ & & $6.68 \mathrm{~s}$ & \\
\hline $5-\mathrm{CH}_{3}$ & $1.27 \mathrm{~d}(6.0)$ & & \\
\hline \multirow[t]{2}{*}{$5-\underline{\mathrm{C}}_{2} \mathrm{OH}$} & & & $3.69 \mathrm{dd}(12.6,6.0)$ \\
\hline & & & $3.59 \mathrm{dd}(12.6,6.0)$ \\
\hline $5-\mathrm{CH}_{2}-\mathrm{OH}$ & & & $5.12 \mathrm{t}(6.0)$ \\
\hline $3^{\prime}, 5^{\prime}-\mathrm{OCH}_{3}$ & $3.75 \mathrm{~s}$ & $3.80 \mathrm{~s}$ & $3.71 \mathrm{~s}$ \\
\hline $3^{\prime \prime}, 5^{\prime \prime}-\mathrm{OCH}_{3}$ & & $3.77 \mathrm{~s}$ & \\
\hline $4^{\prime}-\mathrm{OH}$ & $8.26 \mathrm{~s}$ & $9.08 \mathrm{~s}$ & $8.28 \mathrm{~s}$ \\
\hline $4 "-\mathrm{OH}$ & & $8.51 \mathrm{~s}$ & \\
\hline
\end{tabular}

a) Value in parentheses are coupling constants in $\mathrm{Hz}$.

Table 2. ${ }^{13} \mathrm{C}-\mathrm{NMR}$ Spectral Data for Compounds $\mathbf{1}, \mathbf{2}$ and 3 (in DMSO- $d_{6} 75 \mathrm{MHz}$ )

\begin{tabular}{|c|c|c|c|c|c|c|c|}
\hline $\mathrm{C}$ & 1 & 2 & 3 & $\mathrm{C}$ & 1 & 2 & 3 \\
\hline 1 & & & 79.7 & $4^{\prime}$ & 134.8 & 138.0 & 134.8 \\
\hline 2 & 175.6 & 171.7 & 196.9 & $7^{\prime}$ & & 135.9 & \\
\hline 3 & 37.1 & 130.2 & 127.1 & $1^{\prime \prime}$ & & 122.1 & \\
\hline 4 & 49.0 & 35.4 & 154.4 & $2^{\prime \prime}, 6^{\prime \prime}$ & & 104.1 & \\
\hline 5 & 82.4 & 78.6 & 85.8 & $3^{\prime \prime}, 5^{\prime \prime}$ & & $148.1^{a)}$ & \\
\hline 6 & & & 47.2 & $4^{\prime \prime}$ & & 135.9 & \\
\hline 7 & & & 32.9 & $5-\mathrm{CH}_{3}$ & 18.6 & & \\
\hline $1^{\prime}$ & 128.6 & 124.8 & 127.2 & $5-\mathrm{CH}_{2} \mathrm{OH}$ & & & 62.3 \\
\hline $2^{\prime}, 6^{\prime}$ & 105.3 & 108.2 & 106.5 & $3^{\prime}, 5^{\prime}-\mathrm{OCH}_{3}$ & 56.1 & 56.2 & 56.1 \\
\hline $3^{\prime}, 5^{\prime}$ & 148.1 & $148.0^{a)}$ & 147.7 & $3^{\prime \prime}, 5^{\prime \prime}-\mathrm{OCH}_{3}$ & & 56.2 & \\
\hline
\end{tabular}

a) Interchanged.
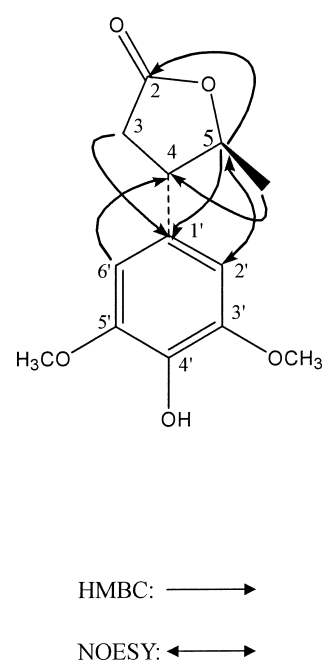

Fig. 1. Important HMBC Correlations and NOESY Correlations of Compound 1

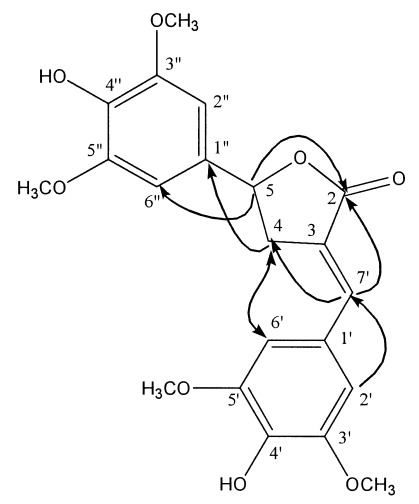

HMBC:

NOESY: $\longleftrightarrow$

Fig. 2. Important HMBC Correlations and NOESY Correlations of Compound 2 
double bond $3\left(7^{\prime}\right)$. Thus, the structure of descurainolide B (2) was elucidated as trans-3-(4-hydroxy-3,5-dimethoxy-benzylidene)-5-(4-hydroxy-3,5-dimethoxy-phenyl)-dihydrofuran-2-one. Compound 2 was a new nor-lignan.

Compound $\mathbf{3}$ was also obtained as colorless needles and positive to the $\mathrm{FeCl}_{3}$ reagent. The molecular formula of $\mathrm{C}_{16} \mathrm{H}_{18} \mathrm{O}_{6}$ was deduced from HR-ESI-MS spectrum. Combined with HMQC, its NMR spectra (Tables 1, 2) showed the same 4-hydroxy-3,5-dimethoxy-phenyl moiety as those of $\mathbf{1}$ and 2; an $\alpha, \beta$-unsaturated carbonyl group on a carbon ring at $\delta_{\mathrm{H}} 6.19(1 \mathrm{H}, \mathrm{d}, 9.9 \mathrm{~Hz})$ and $6.82(1 \mathrm{H}, \mathrm{d}, 9.9 \mathrm{~Hz}), \delta_{\mathrm{C}} 127.1$, 154.4 and 196.9; a hydroxymethyl group at $\delta_{\mathrm{H}} 5.12(1 \mathrm{H}, \mathrm{t}$, $6.0 \mathrm{~Hz}), 3.69(1 \mathrm{H}, \mathrm{dd}, 12.6,6.0 \mathrm{~Hz})$ and $3.59(1 \mathrm{H}, \mathrm{dd}, 12.6$, $6.0 \mathrm{~Hz}), \delta_{\mathrm{C}} 62.3$; a quaternary carbon atom connected with an oxygen atom at $\delta_{\mathrm{C}} 85.8$; a methine group attached to an oxygen atom at $\delta_{\mathrm{H}} 4.51(1 \mathrm{H}$, brd, $8.1 \mathrm{~Hz}), \delta_{\mathrm{C}} 79.7$; another methine group at $\delta_{\mathrm{H}} 3.45(1 \mathrm{H}, \mathrm{dd}, 10.2,7.2 \mathrm{~Hz}), \delta_{\mathrm{C}} 47.2$; and a methylene group at $\delta_{\mathrm{H}} 1.92(1 \mathrm{H}, \mathrm{dd}, 13.5,7.2 \mathrm{~Hz})$ and 2.83 $(1 \mathrm{H}, \mathrm{m}), \delta_{\mathrm{C}} 32.9$. Eight degrees of unsaturation, three attributed to the carbon ring containing the $\alpha, \beta$-unsaturated carbonyl group and four to the phenyl group, indicated the presence of a bridged-ring system. Compared with the NMR spectral data of the known 5-hydroxymethyl-6-(4-hydroxy-3methoxyphenyl)-8-oxa-bicyclo[3,2,1]oct-3-en-2-one, ${ }^{9)}$ a rare aryl-8-oxa-bicyclo[3,2,1]oct-3-en-2-one in nature, a moiety of 8-oxa-bicyclo[3,2,1] oct-3-en-2-one of 3 was suggested. The ${ }^{1} \mathrm{H}-{ }^{1} \mathrm{H}$ COSY spectrum exhibited the connections of $\mathrm{C}-1$ with $\mathrm{C}-7$, and $\mathrm{C}-7$ with $\mathrm{C}-6$, by the cross peaks: $\mathrm{H}-1$ with $\mathrm{H}-$ $7 \alpha$, and $\mathrm{H}-7 \beta$ with $\mathrm{H}-6$. In addition, the connecting order of the 8-oxa-bicyclo[3,2,1]oct-3-en-2-one moiety was established by HMBC (Fig. 3), in which the cross peaks: C-1 with $\mathrm{H}-3$; C-2 with $\mathrm{H}-7 \alpha, 7 \beta$; C-5 with $\mathrm{H}-3$; C-5 with $\mathrm{H}-7 \alpha$; C-4 with $\mathrm{H}-6$; $\mathrm{C}-5$ with $\mathrm{H}-1$, confirmed the connections of $\mathrm{C}-1$ to C-2, C-4 to C-5, C-5 to C-6, and C-1 to C-5 by an oxo bridge which made the cis-orientation of $\mathrm{H}-1$ and the substituent of C-5 necessary. The positions of the hydroxymethyl group and the phenyl group were determined to be C-5 and C-6, respectively, by the cross peaks of HMBC: C-5 with $5-\mathrm{CH}_{2} \mathrm{OH}$; 5- $\mathrm{CH}_{2} \mathrm{OH}$ with $\mathrm{H}-4$; C-6 with $\mathrm{H}-2^{\prime}, 6^{\prime}$; C-2', 6' with H-6. The stereochemistry of $\mathbf{3}$ was revealed by the NOESY experiment. The cross peaks of $\mathrm{H}-1$ and $\mathrm{H}-7 \alpha, \mathrm{H}-7 \alpha$ and $\mathrm{H}-6, \mathrm{H}-$ $7 \beta$ and $\mathrm{H}-2^{\prime}, 6^{\prime}$ showed the same orientation of H-1, H- 6 and $\mathrm{H}-7 \alpha$, and then $5-\mathrm{CH}_{2} \mathrm{OH}$ should also adopt this orientation. Therefore, the relative configuration of $\mathbf{3}$ was identified as the trans-orientation of the phenyl moiety and $5-\mathrm{CH}_{2} \mathrm{OH}$. Thus, the structure of descurainin (3) was elucidated as 5-hydroxymethyl-6-(4-hydroxy-3,5-dimethoxyphenyl)-8-oxa-bicyclo[3,2,1]oct-3-en-2-one.

The cytotoxic potential of the isolated compounds was investigated by determining their concentrations required for $50 \%$ growth inhibition ( $\mathrm{IC}_{50}$ value) for 6 human cancer cell lines. Compounds $\mathbf{4}$ and $\mathbf{5}$ showed cytotoxicity (Table 3). Compound $\mathbf{4}$ exhibited significant cytotoxicity towards human stomach adenocarcinoma cell line, BGC-823 and human breast carcinoma cell line, MDA-MB-435; and moderate activity towards human prostate cancer cell line, PC3M-1E8, human hepatic carcinoma cell line, Bel-7402 and human cervical cancer cell line, HeLa. Compound 5 showed moderate cytotoxicity only towards human acute myeloid leukemia cell line, HL-60. Other isolated compounds showed no or little cytotoxicity.
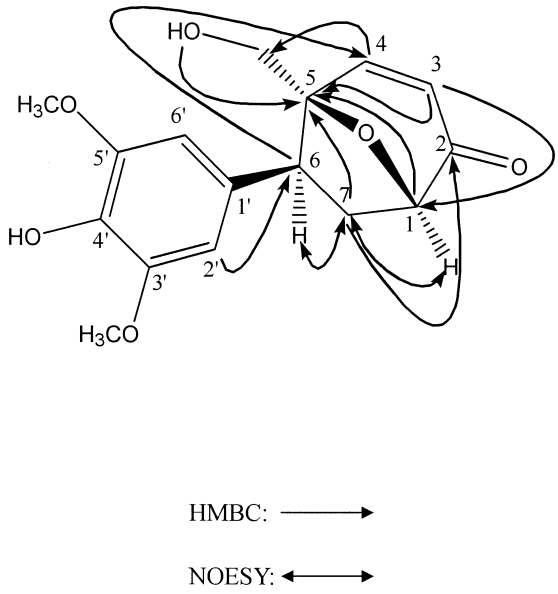

Fig. 3. Important HMBC Correlations and NOESY Correlations of Compound 3

Table 3. Cytotoxicity of Compounds $\mathbf{4}$ and $\mathbf{5}$

\begin{tabular}{lcc}
\hline \hline Cancer cell lines & $\mathrm{IC}_{50}$ of $\mathbf{4}(\mu \mathrm{g} / \mathrm{ml})$ & $\mathrm{IC}_{50}$ of $\mathbf{5}(\boldsymbol{\mu g} / \mathrm{ml})$ \\
\hline HL-60 & $>10$ & 2.24 \\
PC-3M-1E8 & 4.48 & $>10$ \\
BGC-823 & $2.25 \times 10^{-2}$ & $>10$ \\
MDA-MB-435 & 0.142 & $>10$ \\
Bel-7402 & 2.34 & $>10$ \\
Hela & 0.541 & $>10$ \\
\hline
\end{tabular}

\section{Experimental}

General Melting point was measured on a Yamaco micro-hot-stage and is uncorrected. NMR spectra were recorded on a Bruker-ARX-300 spectrometer, using TMS as an internal standard. ESI-MS was performed on a Finnigan LCQ mass spectrometer. HR-ESI-MS was performed on a QSTAR LCQ mass spectrometer. The optical rotation was measured on a PerkinElmer 241 polarimeter. Silica gel for chromatography was produced by Qingdao Ocean Chemical Group Co. Ltd., China. Macroporous resin D101 for chromatography was produced by Nankai University.

Plant Material The plant material was purchased from Shenyang TCM Corporation (Shenyang), and was identified by Prof. Sun Qishi (Shenyang Pharmaceutical University). A voucher specimen (No. 20010321) is deposited in the Research Department of Natural Medicine, Shenyang Pharmaceutical University.

Extraction and Isolation The air-dried seeds $(10 \mathrm{~kg})$ of Descurainia sophia were extracted three times with $70 \%$ ethanol for $2 \mathrm{~h}$ each. The extract was concentrated in vacuo, chromatographed on a D101 macroporous resin column and eluted with $\mathrm{H}_{2} \mathrm{O}, 20 \%, 40 \%, 60 \%$ and $95 \%$ ethanol successively. The $40 \%$ eluate $(100 \mathrm{~g})$ was prefractionated by $\mathrm{CC}$ on silica gel yielding fraction $1\left(\mathrm{CHCl}_{3}-\mathrm{MeOH} 200: 1,1.2 \mathrm{~g}\right)$, fraction $2\left(\mathrm{CHCl}_{3}-\mathrm{MeOH} 100: 1\right.$, $1.0 \mathrm{~g})$ and fraction $3\left(\mathrm{CHCl}_{3}-\mathrm{MeOH} 200: 3,1.3 \mathrm{~g}\right)$, compound 7 $\left(\mathrm{CHCl}_{3}-\mathrm{MeOH} 50: 1\right.$, recrystallized, $\left.235 \mathrm{mg}\right)$, compound $4\left(\mathrm{CHCl}_{3}-\mathrm{MeOH}\right.$ $100: 3$, recrystallized, $275 \mathrm{mg})$, compound $5\left(\mathrm{CHCl}_{3}-\mathrm{MeOH} 200: 11\right.$, recrystallized, $323 \mathrm{mg})$ and compound $8\left(\mathrm{CHCl}_{3}-\mathrm{MeOH} 200: 15\right.$, recrystallized, $175 \mathrm{mg})$. Fraction 1 (1.2 g) was separated by $\mathrm{CC}$ on silica gel eluting with petroleum ether-EtOAc- $\mathrm{Me}_{2} \mathrm{CO}$ to yield compound 6 (15:1:1, recrystallized, $123 \mathrm{mg})$ and compound $1(8: 1: 1$, recrystallized, $103 \mathrm{mg})$. Fraction $2(1.0 \mathrm{~g})$ and fraction $3(1.3 \mathrm{~g})$ were purified, respectively, by recrystallization to yield compound $2(85.7 \mathrm{mg})$ and compound $3(59.2 \mathrm{mg})$

Descurainolide A (1): Colorless needles, mp $117-118^{\circ} \mathrm{C} ;[\alpha]_{\mathrm{D}}^{20}=+0.3^{\circ}$ $\left(c=0.19, \mathrm{Me}_{2} \mathrm{CO}\right)$; ESI-MS: $m / z 253.0[\mathrm{M}+\mathrm{H}]^{+}$and $251.0[\mathrm{M}-\mathrm{H}]^{-}$; HRESI-MS: $m / z 275.0894[\mathrm{M}+\mathrm{Na}]^{+}$(Calcd for $\left.\mathrm{C}_{13} \mathrm{H}_{16} \mathrm{O}_{5} \mathrm{Na} 275.0895\right)$; for NMR spectra, see Tables 1 and 2.

Descurainolide B (2): Colorless needles, mp 201-203 ${ }^{\circ} \mathrm{C} ;[\alpha]_{\mathrm{D}}^{20}=+2.3^{\circ}$ $(c=0.37, \mathrm{MeOH})$; ESI-MS: $m / z 402.8[\mathrm{M}+\mathrm{H}]^{+}$and $400.9[\mathrm{M}-\mathrm{H}]^{-}$; HRESI-MS: $m / z$ 425.1175 $[\mathrm{M}+\mathrm{Na}]^{+}$(Calcd for $\mathrm{C}_{21} \mathrm{H}_{22} \mathrm{O}_{8} \mathrm{Na} 425.1212$ ); for NMR spectra, see Tables 1 and 2.

Descurainin (3): Colorless needles, mp $193-195^{\circ} \mathrm{C} ;[\alpha]_{\mathrm{D}}^{20}=+1.7^{\circ}$ $(c=0.23, \mathrm{MeOH})$; ESI-MS: $m / z 307.0[\mathrm{M}+\mathrm{H}]^{+}$and $304.9[\mathrm{M}-\mathrm{H}]^{-}$; HR- 
ESI-MS: $m / z 329.1011[\mathrm{M}+\mathrm{Na}]^{+}$(Calcd for $\mathrm{C}_{16} \mathrm{H}_{18} \mathrm{O}_{6} \mathrm{Na}$ 329.1001); for NMR spectra, see Tables 1 and 2.

In Vitro Cytotoxic Assay The cytotoxicity of the prepared constituents of the seeds of D. sophia against human acute myeloid leukemia cell line, HL-60, was assessed by the 3-(4,5-dimethylthiazol-2-yl)-2,5-diphenyltetrazolium bromide (MTT) colorimetric method; and the activity towards human stomach adenocarcinoma cell line, BGC-823, human breast carcinoma cell line, MDA-MB-435, human prostate cancer cell line, PC-3M1E8, human hepatic carcinoma cell line, Bel-7402 and human cervical cancer cell line, HeLa was monitored by the sulforhodamine B (SRB) method. Briefly, cells $\left(2.5 \times 10^{4} / \mathrm{ml}\right)$ in RPMI-1640 medium supplemented with $10 \%$ fetal bovine serum were incubated in 96-well plates in the presence of serially diluted samples at $37{ }^{\circ} \mathrm{C}$ in the $5 \% \mathrm{CO}_{2}$ incubator for $48 \mathrm{~h}$. For the MTT method, cells were incubated with MTT for $4 \mathrm{~h}$. Reduced MTT crystals were dissolved in DMSO, and then the absorbance at $570 \mathrm{~nm}$ of each well was measured using an assay plate reader (Tecan, Salzburg, Austria) to determine cell growth inhibition. For the SRB assay, cultured cells fixed with trichloroacetic acid were stained for $30 \mathrm{~min}$ with SRB dissolved in $1 \%$ acetic acid. Unbound dye was removed by four washes with $1 \%$ acetic acid, and protein-bound dye was extracted with $10 \mathrm{~mm}$ unbuffered Tris base (pH 10.5) for $5 \mathrm{~min}$. OD value was read at $540 \mathrm{~nm}$ in an assay plate reader (Tecan, Salzburg, Austria) to determine cell growth inhibition.
Acknowledgements Special thanks are due to the Analytical Detective Center, Shenyang Pharmaceutical University, for recording MS and NMR spectra.

\section{References}

1) Sun K., Li X., Chin. Tradit. Herb. Drugs, 33, U 003 - 005 (2002).

2) Chen Y. Q., Li R. Z., Wang Y. W., Acta Pharm. Sin., 16, 6264(1981)

3) Wang A. Q., Wang X. K., Li J. L., Cui X. Y., Acta Pharm. Sin., 39, 46-51 (2004).

4) Tori K., Ishii H., Wolkowski Z. W., Chachaty C., Tetrohedron Lett., 13, 1077-1080 (1973).

5) Liang H., Zhao Y. Y., Cui Y. J., Liu Q. X., J. Beijing Med. Univ., 32, $223-225(2000)$.

6) Yi X., Shi J. G., Zhou G. X., Xie M. Y., China J. Chin. Mater. Med., 27, 43-45 (2002).

7) Umezawa H., Takeuchi T., Kumada Y., Jpn. Kokai Tokkyo Koho CODEN: JKXXAF JP 5213616319771114 Showa (1977).

8) Niwa T., Doi U., Osawa T., Bioorg. Med. Chem. Lett., 12, 963-965 (2002).

9) Wen Y. S., He Z. R., Xue K. F., Cao F. Y., Chin. Tradit. Herb. Drugs, 17, 122-126 (1986). 